\title{
The Economics of Religion in a Globalizing World: Communist China and Post-Communist Central Europe
}

\author{
Pavol Minárik ${ }^{1, *}$ \\ ${ }^{1}$ Jan E. Pukyně University, Faculty of Social and Economic Studies, Department of Economics and \\ Management, Moskevská 54, 40096 Ústí nad Labem, Czech Republic
}

\begin{abstract}
.
Research background: Religion is often neglected by economists despite the existing studies of its importance for the economy. Religion and culture shape the development of informal and formal institutions and hence impact economic development. Considering the economic importance of China, the religious situation in that country deserves attention; at the same time, due to the peculiar conditions of religion under Communism, the future of religion in China seems rather unclear.

Purpose of the article: The paper proposes that the economics of religion may be useful in the analysis of the religious situation in China. It shows the possibilities of applying the economic approach even where markets are suppressed, such as under Communist rule. In light of economic theory, it shows that the experience of Central European countries under Communist rule, particularly Czechoslovakia, may provide clues about the future of religion in China.

Methods: The paper builds on previous findings in the economics of religion. It reviews the theories concerning the regulation of the religious markets and the effects of deregulation, as well as the theories specifically developed to analyze religion under heavy regelation and the strategies for its survival. The history of Communist China and Czechoslovakia are compared with regard to those theories.

Findings \& Value added: The paper shows the similarities between Communist China and Czechoslovakia. The parallels seem useful to predict the further development of religion in China, including the effect of the possible tightening of anti-religious policies as well as those of deregulation upon the liberalization of the Chinese political regime.
\end{abstract}

Keywords: economics of religion; Communism; China; Czechoslovakia

JEL Classification: $Z 12, P 39$

\footnotetext{
*Corresponding author: pavol.minarik@ujep.cz
} 


\section{Introduction}

Religion is certainly not among the hottest issues in economic research. However, over recent decades, it has attracted some attention among economists. This is in line with the general development in the field, which increasingly recognizes the role of institutions and culture, as well as with the imperialist ambitions of economists (see [1] and [2], respectively). The economics of religion provides interesting insights both for economists and for researchers in other disciplines dealing with religion.

The economics of religion has already gained some recognition. After all, interest in religion is not novel; it can be traced back to Adam Smith's Wealth of Nations, the founding father of political economy [3]. More recently, the interest in the economic analysis of religion was revived in the imperialist transformation of economics in the 1970s, starting with the seminal paper of Azzi and Ehrenberg [4], and particularly extended in the works of Gary Becker's student, Laurence Iannaccone (notably in his writing of the early 1990s, see $[5,6,7])$. Advances in the field may be followed in the review articles published in the Journal of Economic Literature [8, 9].

Religion, and culture in general, deserve the attention of economics because of their impact on institutions and economic performance $[10,11]$. They specifically deserve attention in countries that are among the major players in the globalizing world. Among them, China stands out for several reasons: It is a country with a diverse religious mix of Asian religions (Buddhism and Daoism), Islam and Western Christianity, combined with a high level of government-sponsored atheism. The anti-religious activities of the Communist authorities may be especially difficult to understand for Western observers. The experience of the Central European post-communist countries may be useful in studying religion in China, while the economics of religion may provide a suitable methodological background for comparative studies.

The economics of religion in Communist countries has received limited attention so far. The most important contributions are those of Fenggang Yang, which deal with religion in China (summarized in [12]). Central European Communist countries also received some attention from the economic perspective $[13,14]$. Otherwise, Central and Eastern Europe is mostly analyzed with regard to the development of religiosity in the post-communist period.

This paper focuses on two issues. First, it shows that, although the economics of religion was originally developed to explain the religious market in the West, it is also applicable to the heavily regulated markets of communist countries. Second, it outlines the application of economic tools in the specific situation of Communist Czechoslovakia and China. The aim is to explore parallels between the two countries with the possible implication for the prediction of the religious future of China.

The paper is organized as follows. The first part outlines the approach of the economics of religion and presents the theories relevant for the economic analysis of religion under communist rule. The second part focuses specifically on the cases of Communist Czechoslovakia and China in the perspective of the economic approach. The final part discusses the observations and formulates predictions for future development.

\section{Methods: The approach of the economics of religion}

The economics of religion has been developed in two lines. The first line applies economic methods to explain religious behavior; this line started with Adam Smith, and it has been rapidly developed in the imperialist tradition. The other line deals with the effects of religion on economic development; it began with Max Weber's Protestant Ethics and the Spirit of Capitalism. Both lines have produced theories and tested them against empirical 
evidence; they belong to positive science and should be distinguished from 'religious economics,' which represents normative economic analysis informed by religious principles [8].

\subsection{Religion as a market phenomenon}

The economics of religion analyzes religion as a market phenomenon using the standard economic model of demand and supply. The demand for religion is the pursuit of goods and services that satisfy religious needs. The supply is the production of such goods and services by religious organizations. The religious market is formed by current and potential adherents and religious organizations seeking to attract or maintain adherents [15].

The demand for religion typically receives more attention from sociologists. The secularization hypothesis, prominent in the sociology of religion, deals with changes in the religious demand, particularly the decline of the demand. Although economists acknowledge the possibility of shifting demand, they typically focus on the supply side of the religious market.

Supply-side theories emphasize the effects of competition. The economics of religion has focused on the problem of competition and regulation from the beginning. Adam Smith, in the Wealth of Nations, was the first one to postulate the detrimental effect of a monopoly in the religious market, and his analysis is surprisingly modern [3]. In recent decades, similar ideas were formulated by Iannaccone [16] and sociologists following the rational choice tradition, Stark and Finke [15], and empirical evidence has been accumulated to support the theory [17 - 19].

The common wisdom is that a monopoly in a religious market, similar to a monopoly in other markets, tends to increase prices and decrease quality. The low quality of religious goods consequently decreases religious participation. On the other hand, competition in an unregulated market should increase both the quality of services and participation. Thus, deregulation provides a major impulse for an increase in religiosity, often dubbed a 'religious revival.'

\subsection{Religion under heavy regulation}

Most of the research focuses on a regulation that seeks to promote a particular religious group. However, the regulation in communist countries sought to eliminate religion as such. Such a situation could be interpreted as state support for the official atheist doctrine, which would be understood as just another competitor in the religious market. However, in addition to that support, the communist state also seeks to increase the costs of participation in any religion present in the market.

Several theories have been developed to address the particular characteristics of the oppressive regulation in communist countries. Fenggang Yang formulated a theory of tripartite religious market under communist rule [20]. Further, he formulated a theory focusing on the demand for religion under communist rule [21]. On the supply side, Minarik developed a model explaining the choice of a religious group between legal and illegal operation $[13,14]$.

Yang defined triple markets - red, black, and gray - that evolve under heavy regulation [20]. The red market comprises officially permitted religious activities. That market is not equally open to all religious groups, and those groups that gain access offer religious goods that are either watered down or that have added communist elements. The black market comprises illegal religious activities that are conducted underground, in secrecy. Religious organizations have more freedom in the underground; however, they typically face high costs of operation. The gray market comprises religious activities with ambiguous legal 
status, neither sanctioned by the state nor prohibited. The costs are relatively lower compared to the black market, and the level of freedom is higher compared to the red market.

Further, Yang formulated three propositions regarding the triple markets under heavy regulation [20]. First, that the black market will emerge in spite of high costs; second, that the gray market will emerge where the red market is restricted and the black market is suppressed; and third, that the extent of the gray market increases with a more restrictive regulation. Religious services provided in the different markets are substitutes, and people do respond to the changes in relative prices or costs. According to Yang, the gray market is critically important for the survival of religion under communist rule.

In another paper, Yang shifts attention to the demand side, namely to the response of religionists facing the shortage in supply caused by oppressive regulation [21]. Following the economic theory concerning the shortage economy (as advanced by Janos Kornai), Yang postulates that consumers in the shortage economy have several options. If they are lucky enough, they might find the appropriate goods available, but often it is necessary to queue up to get them. Frequently, the goods are not available, and the consumers have to search, suppress their demand, or seek substitutes. Those strategies also apply to the consumers in a religious economy under communist rule.

Minarik focuses on the supply side [13]. The paper attempts to explain the behavior of religious organizations under oppressive regulation, such as that under communist rule; particularly, it asks why churches in such conditions sometimes choose to operate both legally and illegally. The model assumes that churches aim to maximize the consumer welfare of religionists, and it shows that the dual operation is preferable in achieving that aim, compared to the solely legal or illegal provision of religious services. In reality, the choice of the religious organization between legal and illegal operation depends on the costs imposed by the government and the set-up costs of the dual operation.

That theory is further developed [14] into three propositions regarding the behavior of a church under oppressive regulation: first, that the church will strive to remain in the official market if the costs are not excessive. The rationale for that proposition is that the church wants to prevent cost-sensitive religionists from substitution. The second proposition states that the high costs of participation in black-market religious activities increase benefits from such participation. This claim is derived from Iannaccone's works [6, 7]. Finally, the third proposition states that if the church can diversify its operations, and the demand is heterogeneous, it is advantageous to operate in multiple markets, which is a reiteration of the previous model [13].

The methodological approach outlined above may serve several purposes. It may be used to interpret past development in religious markets. It may also be employed to formulate predictions about future development. Finally, it may provide a framework for comparative studies of different religious markets. In the following part, the economic theories are used as a framework for such a comparison and further, in the discussion, as a tool for predicting the possible future of religion in China.

\section{Results: Religion in communist countries}

The theories outlined above were formulated to explain the particular situations in Chinese and Czechoslovak religious markets under communist rule. Despite the many historical, cultural and political differences between China and Czechoslovakia, there are striking similarities between those two countries when it comes to the religious market under communism. For comparative purposes, the focus here is on Christianity, particularly the Catholic Church. 


\subsection{China}

Yang provides a good overview of Chinese religious economy [12]. The Communist antireligious policy varied through four periods. From 1949 to 1957, the Communists suppressed all religions but five: Buddhism, Daoism, Islam, Protestantism, and Catholicism, for which they established 'patriotic' religious associations. Then, until 1966, the number of religious venues was forcefully reduced. Between 1966 and 1979 all religious venues were shut down, and religion was banned. Since 1979, there has been a limited tolerance of certain religious groups with increasingly restrictive regulations.

The earlier periods are characterized by severe oppression. The formation of 'patriotic' association met with opposition among Catholic clergy. The Communists responded with severe crackdowns and expelled Catholic foreigners including Vatican representatives, bishops and members of religious orders. The hardest anti-religious campaign came as a part of the Cultural Revolution starting in 1966 that was to end the 'Four Olds,' that is, old customs, old culture, old habits, and old ideas; religion was part of those 'Four Olds.' The Cultural Revolution caused extensive suffering and destruction of cultural values. Interestingly, it also created a quasi-religious personality cult of Mao.

Starting in the 1980s, China has tolerated five major religions organized in the 'patriotic' associations, but no group outside of those associations or any other religion is tolerated. The government actively enforces the rules, such as in the cases of Falun Gong in the late 1990s and Protestant house churches in recent years. Yet, religion is alive and growing in China. Illegal religious groups, such as the underground Catholic Church and several Protestant churches, still attract a number of religionists. There is also significant growth in the gray market of folk religions and loosely organized religious practices.

\subsection{Czechoslovakia}

The situation in Czechoslovakia is better known among the scholars in Central Europe although it has received relatively less attention among international scholars than Poland or Russia (see [14] for a review of the literature). Communist oppression evolved through the three periods of Communist rule; it was the most severe in the initial period after the coup d'état of 1948, then relaxed in the period of Prague Spring in the 1960s, and tightened again in the period of 'normalization' after the Soviet invasion of Czechoslovakia in 1968. The mode of operation for churches was set up in the early years and developed later in response to the changes in government policies.

The main target of Communist anti-church measures was the Catholic Church. It was the dominant religious group, and, with its hierarchical structure and international connections, it was best equipped to challenge the Communist power. The Communists implemented a 'carrot and stick' strategy: on one hand, they lured priests into collaboration with 'patriotic' clergy associations and established state-paid salaries to make the clergy dependent on Communist authorities. On the other hand, the Communists used physical force and intimidation against those who refused to submit to their rules, including show trials, imprisonment in labor camps and executions.

The Catholic Church diversified its operation under Communist rule. The majority of the Catholic clergy accepted the regulations imposed by the Communist government, but only a small portion of them actively collaborated with the Communists in the 'patriotic' associations. Legal operation was forbidden for a significant part of the clergy. In the 1950 s, many priests were put into prisons and labor camps; they often used the prison time as an opportunity for spiritual training and networking. Later, in the period of normalization, the underground Catholic Church emerged as a well-organized structure providing an alternative, or a complement, to the official church [14]. 
The post-communist development in Czechia, Slovakia and other Central European countries is characterized by an initial revival of religiosity after the collapse of communist regimes followed by a gradual decline in later years. There are different theories explaining such development. Both the secularization theory and the supply-side explanation have their shortcomings, and the development may in part be explained by the initial economic collapse and subsequent growth of the post-communist countries [22]. Generally, the communist-imposed secularization may have had some impact on religion in the postcommunist countries, yet religion has shown significant persistence. Moreover, religion seems to affect socio-economic attitudes also in the post-communist transition, and it may have contributed to the different routes of post-communist transition in different countries [23].

\subsection{A comparison in the economic perspective}

Religious markets under communist rule appear surprisingly similar in Czechoslovakia and China. Although the methods and the severity of the oppression differ, in both countries the anti-religious measures have significantly affected the functioning of religious organizations. Also, the responses of Christian religious groups show similarities.

First, let us consider the effect on the demand for religion. Yang states that the demand for religion is persistent [21]. Religionists choose to search, queue or seek substitutes to get religious services and suppress the demand if other strategies are not possible. Persistence of the demand manifested both in Czechoslovakia and in China; when the regulation was relaxed, religiosity increased in both countries. The substitution strategy also manifested in both countries. It was more significant in China, where the oppression was more severe, and folk religions offered alternatives to the officially-sanctioned and illegal religions. Also, the quasi-religious personality cult of the communist leader was more developed in China.

Second, in both countries the religious economy split into the red, black and gray markets in line with the prediction of Yang [20]. Some religious leaders and some religionists accepted the rules imposed by the communists and even collaborated with them (the red market), while others chose the illegal way of operation (the black market). In both countries, there were religious representatives that formally subjected themselves to the communist regulations, and they could minister legally although they also engaged in activities that were not sanctioned by the communist authorities (the gray market).

The lines between the red, the black, and the gray markets do not only separate different religions, but also different groups within religious denominations. As a prime example, the Catholic Church in both countries chose to operate both legally and illegally, thus serving different groups of believers. It is interesting that the Catholic Church, despite its hierarchical structure, has been able to operate in this way, and the similarity between Czechoslovakia and China proves that such ability to adapt to unfavorable regulations is not peculiar to the Catholic religion in one country only. Protestant denominations also opted for simultaneous above- and underground operation in both countries. Those observations follow the predictions of Minarik [13, 14].

To sum up, there are similarities between Czechoslovakia and China, and those similarities follow the theoretical predictions formulated within the rational-choice approach to the study of religion. One could perhaps list many differences between the two countries. Those would not be surprising, given the different historical, cultural, political and religious backgrounds. Nevertheless, it is the similarities that provide backing to the theories advanced by the economic approach. 


\section{Discussion and outlook}

Religion is definitely not the top issue in economic research; yet, economists obviously have something to say about 'the human side of religion' (to borrow from the subtitle of the book by Stark and Finke [15]). Although it may be difficult to define religious goods, it does not mean that religion cannot be analyzed as a market phenomenon. Moreover, the economic approach may be useful both to formulate theoretical predictions and as a framework for a cross-country analysis.

The economics of religion has something to say not only about the religious markets, but also about the effects of their regulation and suppression in communist countries. The theories outlined in the paper address both demand and supply in the religious market. Facing oppressive regulation under communist rule, religionists and religious organizations choose strategies that are different from those in free societies.

There are significant parallels between Communist Czechoslovakia and China. In the case of Czechoslovakia, researchers are in a better position; they have access to historical data on both government policies and the behavior of the believers and the churches. Also, they have the benefits of hindsight, and they can assess the outcomes of the regulation being removed. Findings from Czechoslovak history might be relevant for the assessment of the situation in China. Since China is among the hot issues in social scientific study of religion, the parallels between China and Czechoslovakia seem worth exploring.

Following the similarities between Czechoslovakia and China, we may speculate about the possible future development of religion in China. It is well possible that the relaxing of restrictions in the Chinese religious market will result in significant religious growth, that is, a religious revival in China. The development in recent decades provides some support for that scenario. However, it is difficult to estimate the effect of anti-religious indoctrination in the Asian context; this is where the experience of the Central European countries is not useful.

Furthermore, similar to that in Central Europe [22], future economic development in China may be important. Economic recession combined with regime change and the resulting existential insecurity would provide more fuel for religious sentiment [24]. On the other hand, continuous economic growth and increasing welfare might discourage religiosity in the same way as those factors did in Central Europe.

Moving beyond the general observations about religiosity, what matters is the religious composition [10,23]. It is impossible to predict which religious groups would grow in China if the restrictions were removed. Both Christianity and Islam have shown significant viability. Both religions could possibly receive support from abroad. However, unlike Christianity, Islam seems to be bound to particular ethnic groups. Also, Buddhism and Daoism have long traditions in China.

The possible growth of Western Christianity may affect the institutional and economic development of China. Previous studies have shown some positive impact of Western Christianity on economic development, including that in post-communist transition (see [10] and [23]). On the other hand, the Muslim presence in China, with the overlap of religious and ethnic groups, may be a source of possible conflicts similar to those in postcommunist Yugoslavia and some Central Asian countries. However, the overlap of religion, ethnicity and politics is beyond the scope of this paper.

Finally, it is important to stress the limits of the present analysis. The disputes about the relevance of the economics of religion seem less important in the present context. What matters is the important differences between China and Central Europe in culture, history, geography and politics. Even though economists tend to postulate general prediction based on assumptions that are constant (typically the assumption of rational choice), one must be very cautious when it comes to complex phenomena such as religion. 
There are many factors that may play a role in future development that are difficult to implement with an economic model. Thus, this paper should be viewed rather as a sketch of a possible approach to the analysis of the future of religion in China. Also, it is intended as a reminder to the economists that they should not disregard religion, both because religion matters and because economists may bring useful insights into the social scientific study of religion.

This research was supported by the Czech Science Foundation (grant no. 19-07748S).

\section{References}

1. Beugelsdijk, S., Maseland, R. (2011). Culture in economics: History, methodological reflections and contemporary applications. Cambridge: Cambridge University Press.

2. Lazear, E.P. (2000). Economic imperialism. Quarterly Journal of Economics, 115(1), 99-146.

3. Anderson, G.M. (1988). Mr. Smith and the preachers: The economics of religion in the Wealth of Nations. Journal of Political Economy, 96(5), 1066-1088.

4. Azzi, C., Ehrenberg, R.G. (1975). Household allocation of time and church attendance. Journal of Political Economy, 83(1), 27-56.

5. Iannaccone, L.R. (1990). Religious practice: A human capital approach. Journal for the Scientific Study of Religion, 29(3), 297-314.

6. Iannaccone, L.R. (1992). Sacrifice and stigma: Reducing free-riding in cults, communes, and other collectives. Journal of Political Economy, 100(2), 271-291.

7. Iannaccone, L.R. (1994). Why strict churches are strong. American Journal of Sociology, 99(5), 1180-1211.

8. Iannaccone, L.R. (1998). Introduction to the economics of religion. Journal of Economic Literature, 36(3), 1465-1495.

9. Iyer, S. (2016). The new economics of religion. Journal of Economic Literature, 54(2), 395-441.

10. Guiso, L., Sapienza, P., Zingales, L. (2003). People's opium? Religion and economic attitudes. Journal of Monetary Economics, 50(1), 225-282.

11. Guiso, L., Sapienza, P., Zingales, L. (2006). Does culture affect economic outcomes? Journal of Economic Perspectives, 20(2), 23-48.

12. Yang, F. (2012). Religion in China: Survival and revival under communist rule. New York: Oxford University Press.

13. Minarik, P. (2018). An economic model of religious organization under oppressive regulation. Journal of Economics, 124(3), 289-302.

14. Minarik, P. (2019). A religious organization under oppressive regulation: The official and underground church in Czechoslovakia. SSRN.

http://dx.doi.org/10.2139/ssrn.3506694

15. Stark, R., Finke, R. (2000). Acts of faith: Explaining the human side of religion. Berkeley: University of California Press.

16. Iannaccone, L.R. (1991). The consequences of religious market structure: Adam Smith and the economics of religion. Rationality and Society, 3(2), 156-177.

17. Finke, R., Stark, R. (1988). Religious economies and sacred canopies: Religious mobilization in American cities, 1906. American Sociological Review, 53(1), 41-49. 
18. Finke, R., Stark, R. (2005). The churching of America, 1776-2005: Winners and losers in our religious economy. Piscataway, NJ: Rutgers University Press.

19. Stark, R., Iannaccone, L.R. (1994). A supply-side reinterpretation of the "secularization" of Europe. Journal for the Scientific Study of Religion, 33(3), 230-252.

20. Yang, F. (2006). The red, black, and gray markets of religion in China. Sociological Quarterly, 47(1), 93-122.

21. Yang, F. (2010). Religion in China under communism: A shortage economy explanation. Journal of Church and State, 52(1), 3-33.

22. Minarik, P. (2014). Employment, wages, and religious revivals in postcommunist countries. Journal for the Scientific Study of Religion, 53(2), 296-315.

23. Minarik, P. (2014). Religion and economic attitudes in post-communist transition. Post-Communist Economies, 26(1), 67-88.

24. Norris, P., Inglehart, R. (2004). Sacred and secular: Religion and politics worldwide. Cambridge: Cambridge University Press. 